
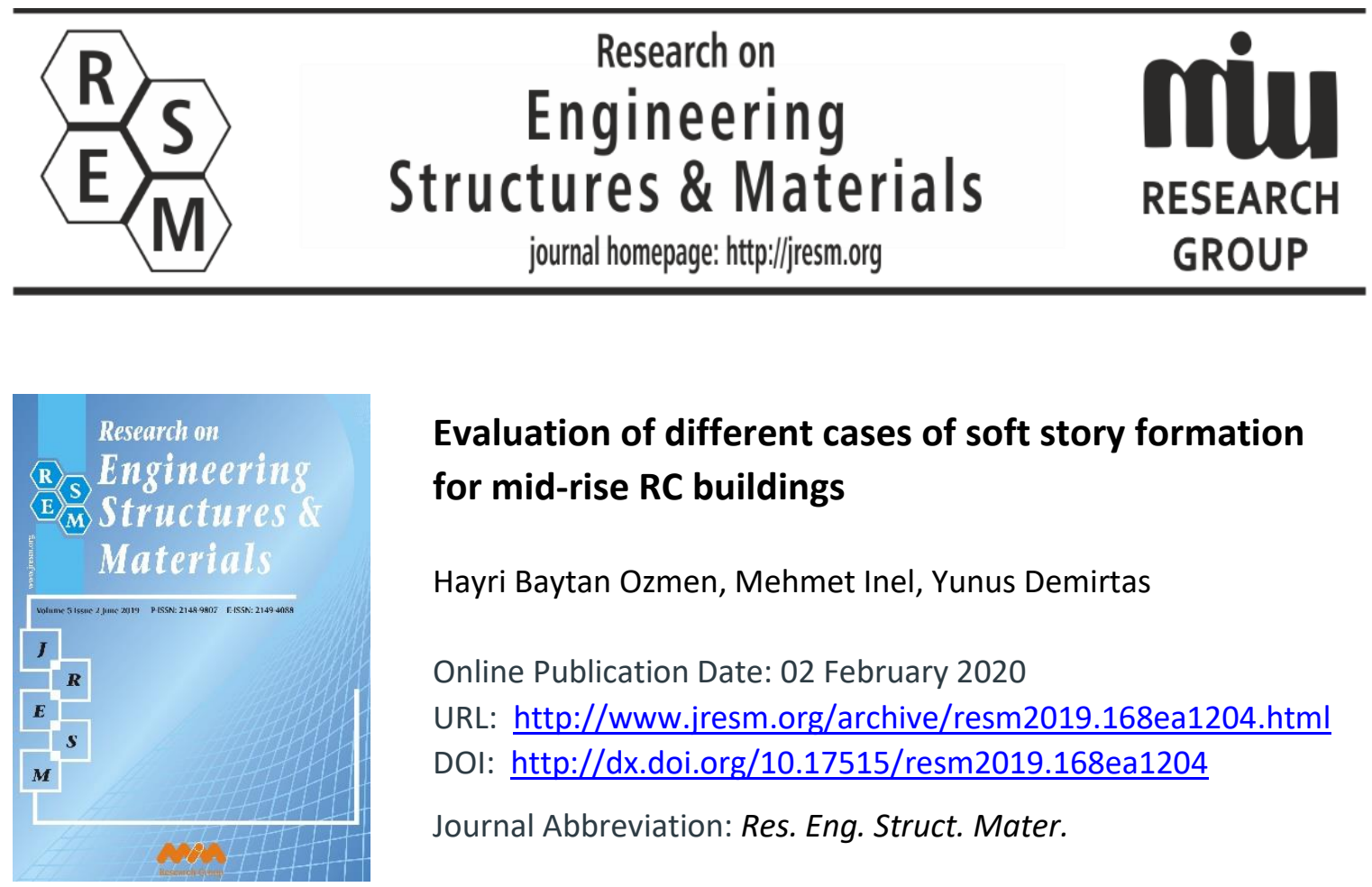

\title{
Evaluation of different cases of soft story formation for mid-rise RC buildings
}

Hayri Baytan Ozmen, Mehmet Inel, Yunus Demirtas

Online Publication Date: 02 February 2020

URL: http://www.jresm.org/archive/resm2019.168ea1204.html

DOI: http://dx.doi.org/10.17515/resm2019.168ea1204

Journal Abbreviation: Res. Eng. Struct. Mater.

\section{To cite this article}

Ozmen HB, Inel M, Demirtas Y. Evaluation of different cases of soft story formation for midrise RC buildings. Res. Eng. Struct. Mater., 2020; 6(3): 229-240.

\section{Disclaimer}

All the opinions and statements expressed in the papers are on the responsibility of author(s) and are not to be regarded as those of the journal of Research on Engineering Structures and Materials (RESM) organization or related parties. The publishers make no warranty, explicit or implied, or make any representation with respect to the contents of any article will be complete or accurate or up to date. The accuracy of any instructions, equations, or other information should be independently verified. The publisher and related parties shall not be liable for any loss, actions, claims, proceedings, demand or costs or damages whatsoever or howsoever caused arising directly or indirectly in connection with use of the information given in the journal or related means.

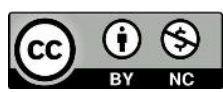
Published articles are freely available to users under the terms of Creative Commons Attribution - NonCommercial 4.0 International Public License, as currently displayed at here (the "CC BY - NC"). 


\title{
Research on Engineering Structures \& Materials
}

journal homepage: http://jresm.org

Research Article

\section{Evaluation of different cases of soft story formation for mid-rise RC buildings}

\author{
Hayri Baytan Ozmen ${ }^{1, a}$, Mehmet Inel2,b, Yunus Demirtas*1,c \\ ${ }^{1}$ Department of Civil Engineering, Usak University, Usak, Turkey. \\ ${ }^{2}$ Department of Civil Engineering, Pamukkale University, Denizli, Turkey.
}

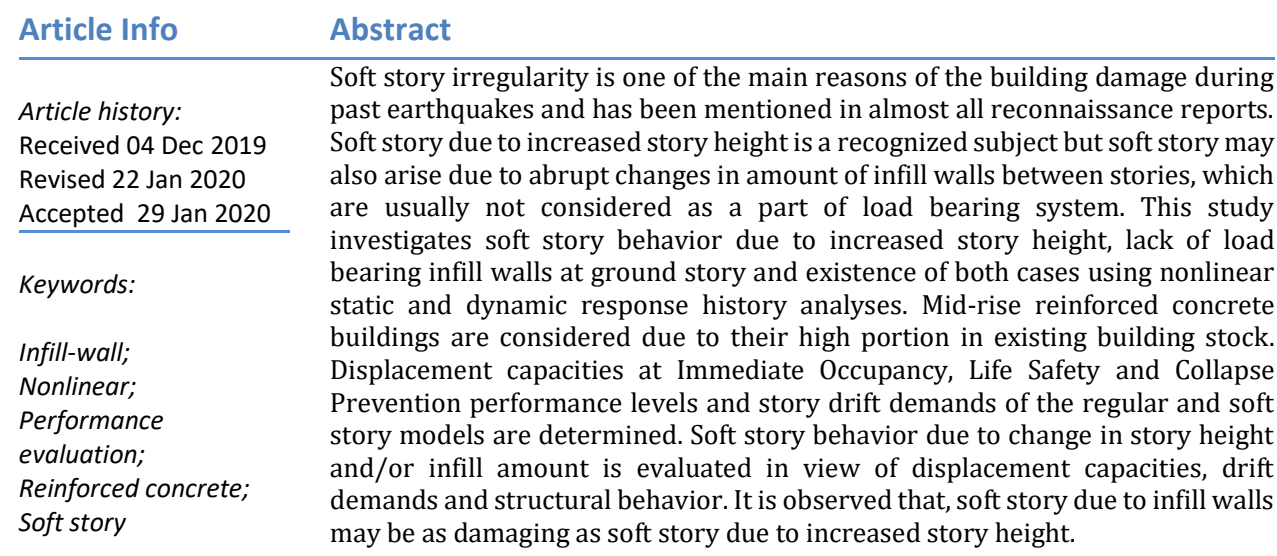

(C) 2020 MIM Research Group. All rights reserved.

\section{Introduction}

Soft story irregularity is one of the main reasons of building damages during recent earthquakes in the world as mentioned in almost all reconnaissance reports and studies [1-6]. Previous studies have shown that infill walls have also an important influence on the formation of structural irregularities such as soft floors, weak floors, torsional irregularity and short columns [7-10]. Soft story may arise not only because of sudden changes in structural system (like height of the stories) but also due to abrupt changes in amount of infill walls between stories. Although they are not included in the load bearing system, infill walls affect the seismic behavior of the structure [11-13]. Inappropriate placed infill walls may also adversely affect the dynamic characteristics of the structures [14]. Furthermore, the infill walls may increase the base shear capacity while reducing the fragility of the structure $[15,16,17]$.

This study aims to investigate soft story behavior using nonlinear static and dynamic response history analyses for mid-rise RC buildings which are thought to be the most vulnerable in existing building stock. The 4- and 7-storey 3-D building models are designed per premodern earthquake codes to reflect existing mid-rise building stock [18]. Soft story models of the reference buildings are obtained considering increased floor story height, less amount of infill at floor story and both cases. Capacity curves are obtained using nonlinear static analyses. Displacement capacities of the reference and soft story models

\footnotetext{
${ }^{*}$ Corresponding author: yunus.demirtas@usak.edu.tr

a orcid.org/0000-0001-6750-8632; b orcid.org/0000-0002-8323-259X; c orcid.org/0000-0002-7992-493X; DOI: http://dx.doi.org/10.17515/resm2019.168ea1204
}

Res. Eng. Struct. Mat. Vol. 6 Iss. 3 (2020) 229-240 
are determined at Immediate Occupancy, Life Safety and Collapse Prevention performance levels according to 2018 Turkish Building Earthquake Code [19]. Building models are reduced to "Equivalent" Single-Degree-of-Freedom systems. These models are subjected to 83 different earthquake records and then inter-story drift demands at the ground story (soft story) are determined by using mode shape of the buildings. Nonlinear static analyses are performed using SAP2000 [20]. Beam and column elements are modeled as nonlinear frame elements with lumped plasticity by defining plastic hinges at both ends of beams and columns. Effect of infill walls is modeled through diagonal struts as suggested in FEMA356 [21]. Shear hinges take into account possible shear failures in existing reinforced concrete buildings. All buildings are modeled with two different transverse steel amounts to investigate the effect of transverse steel on the behavior. Soft story behavior due to change in story height and/or infill amount is evaluated in view of displacement demands, capacities and structural behavior. The outcomes are useful to better understand soft story damages during past earthquakes and to emphasize the effect of infill walls on the behavior.

\section{Aim and Scope}

Soft story behavior due to increased story height is a well-known subject among civil engineering professionals. But soft-story problems may arise due to many different reasons like changes in load carrying [22] and slab system [2] between stories. Among others, one of the most frequent reasons of the soft story behavior is the abrupt change in the amount of the infill walls between stories. As the infill walls are not regarded as a part of load carrying system, generally civil engineers do not consider their effects on the structural behavior. Therefore, many civil engineers are not conscious enough about soft story occurrence because of infill walls, and required attention is not provided. In this study, effect of infill walls on structural behavior, especially for the soft story, is investigated in order to increase the level of knowledge and awareness on the subject.

The major portion of the building stock of many developing countries consists of deficient mid-rise reinforced concrete buildings. In scope of the study, soft story behavior in existing mid-rise reinforced concrete buildings below code requirements are investigated. Two sets of RC buildings 4-story and 7-story are selected to represent mid-rise buildings located in the high seismicity region of Turkey, five buildings in each set. The selected buildings are typical beam-column RC frame buildings with no shear walls. Since in Turkey still the majority of buildings were constructed according to 1975 Turkish Earthquake Code, the 4- and 7-story buildings are designed according this code considering both gravity and seismic loads (a design ground acceleration of $0.4 \mathrm{~g}$ and soil class $\mathrm{Z} 3$ that is similar to class $C$ soil of FEMA-356 is assumed [21]. Material properties are assumed to be $16 \mathrm{MPa}$ for the concrete compressive strength and $220 \mathrm{MPa}$ for the yield strength of both longitudinal and transverse reinforcement. Strain-hardening of longitudinal reinforcement has been taken into account and the ultimate strength of the reinforcement is taken as $330 \mathrm{MPa}$ [23]. One of the important deficiencies in the existing building stock is insufficient amount of transverse reinforcement. The transverse reinforcement amount may be considered to represent construction and workmanship. Two different spacings are considered as $100 \mathrm{~mm}$ and $200 \mathrm{~mm}$ to investigate soft story behavior with different ductility.

\section{Building Models}

The selected 4- and 7-story buildings a have the same plan view as shown in Fig. 1, with 4 bays in $\mathrm{X}$ and $\mathrm{Y}$ direction as $4 \mathrm{~m}$ and $3 \mathrm{~m}$, respectively. Regular story height is $2.8 \mathrm{~m}$. In the figure, the infill walls that meet the requirements of FEMA 356 to form diagonal struts are shown with shaded areas. More detailed information about models are given in [24]. The 
other infill walls with openings that prevent diagonal strut formation are considered as dead loads, only. The 4- and 7-story buildings have symmetrical floor plans to avoid any irregularity effects.

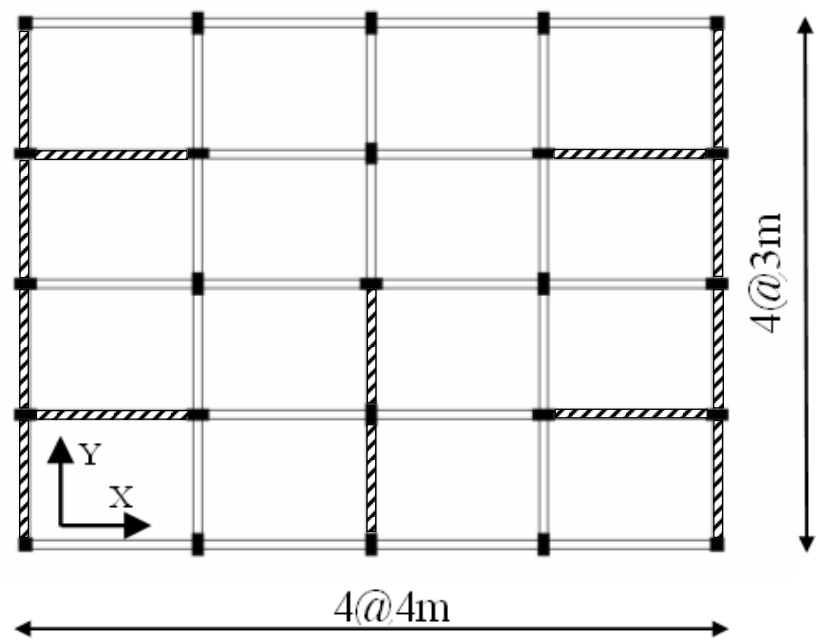

Fig. 1 Plan view of the selected 4- and 7-story buildings

Soft story effect in this study is considered by (i) increasing story height (4 $\mathrm{m}$ instead of $2.8 \mathrm{~m}$ ) at the ground floor, (ii) assuming less amount of infill walls at the ground floor and the existence of the issues (i) and (ii) at the same time is also considered. Source of soft story, model identifier, period of first mode considering cracked section stiffness ( $T$ ), ratio of yield lateral strength to the seismic weight of building ( $\mathrm{Cy}$ ) values of the building models is given in Table 1. Note that RefNW buildings (reference buildings with no infill effect) are modeled to better understand the effect of neglecting walls as load carrying elements on the building behavior. The last letters in the model identifier express the considered principal direction.

Table 1 Properties of building models

\begin{tabular}{cccccc}
\hline & & \multicolumn{2}{c}{ 4-story } & \multicolumn{2}{c}{ 7-story } \\
\cline { 3 - 6 } Source of Soft Story & Model & T (s) & $\mathbf{C}_{\mathbf{y}}$ & $\mathbf{T}(\mathbf{s})$ & $\mathbf{C}_{\mathbf{y}}$ \\
\hline \multirow{2}{*}{ Reference regular building } & Ref-X & 0.57 & 0.17 & 0.89 & 0.15 \\
& Ref-Y & 0.47 & 0.25 & 0.75 & 0.18 \\
\hline Reference regular building without & RefNW-X & 0.84 & 0.14 & 1.12 & 0.12 \\
diagonal struts at any story & RefNW-Y & 0.81 & 0.15 & 1.1 & 0.13 \\
\hline Soft story due to increased ground story & SSH-X & 0.67 & 0.16 & 0.97 & 0.13 \\
height (2.8 m to 4 m) & SSH-Y & 0.54 & 0.21 & 0.83 & 0.16 \\
\hline Soft story due to absence of walls at & SSW-X & 0.63 & 0.17 & 0.91 & 0.14 \\
ground story & SSW-Y & 0.55 & 0.2 & 0.79 & 0.17 \\
\hline Soft story due to increased height and & SSHW-X & 0.84 & 0.13 & 1.05 & 0.12 \\
absence of walls at ground story & SSHW-Y & 0.77 & 0.14 & 0.94 & 0.13 \\
\hline
\end{tabular}




\subsection{Modeling Approach}

Nonlinear static analyses have been performed using SAP2000 Nonlinear Version 8 that is a general-purpose structural analysis program [20]. Three-dimensional model of each structure is created in SAP2000 to carry out nonlinear static analysis. Beam and column elements are modeled as nonlinear frame elements with lumped plasticity by defining plastic hinges at both ends of beams and columns. SAP2000 implements the plastic hinge properties described in FEMA-356 (or ATC-40) [21, 25]. As shown in Figure 2, five points labeled A, B, C, D, and E define force-deformation behavior of a plastic hinge.

The definition of user-defined hinge properties requires moment-curvature analysis of each element. Modified Kent and Park model [26] for unconfined and confined concrete and typical steel stress-strain model with strain hardening [27] for steel are implemented in moment-curvature analyses. The points B and C on Fig. 2 are related to yield and ultimate curvatures. The point B is obtained from SAP2000 using approximate component initial effective stiffness values as per TEC-2007; 0.4EI for beams and values depending on axial load level for columns: $0.4 \mathrm{EI}$ for $\mathrm{N} /(\mathrm{Acfc}) \leq 0.1$ and $0.8 \mathrm{EI}$ for $\mathrm{N} /(\mathrm{Acfc}) \geq 0.4$. fc is concrete compressive strength, $\mathrm{N}$ is axial load, $\mathrm{Ac}$ is area of section. For the $\mathrm{N} /$ (Acfc) values between 0.1 and 0.4 linear interpolation is made [28].

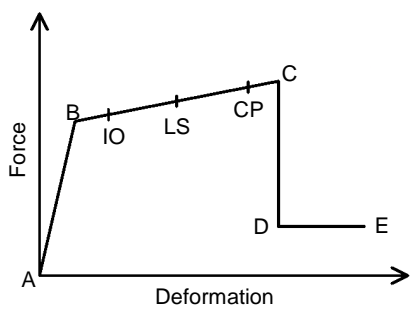

Fig. 2 Force-Deformation relationship of a typical plastic hinge

The ultimate curvature is defined as the smallest of the curvatures corresponding to (1) a reduced moment equal to $80 \%$ of maximum moment, determined from the momentcurvature analysis, (2) the extreme compression fiber reaching the ultimate concrete compressive strain as determined using the simple relation provided by Priestley et al. [29] given in Eqn. 1, and (3) the longitudinal steel reaching a tensile strain of $50 \%$ of ultimate strain capacity that corresponds to the monotonic fracture strain. Ultimate concrete compressive strain is given as:

$$
\varepsilon_{c u}=0.004+\frac{1.4 \rho_{s} f_{y h} \varepsilon_{s u}}{f_{c c}}
$$

where $\varepsilon_{\mathrm{cu}}$ is the ultimate concrete compressive strain, $\varepsilon_{\mathrm{su}}$ is the steel strain at maximum tensile stress, $\rho_{\mathrm{s}}$ is the volumetric ratio of confining steel, $f_{\text {yh }}$ is the yield strength of transverse reinforcement, and $\mathrm{f}_{\mathrm{cc}}$ is the peak confined concrete compressive strength.

The input required for SAP2000 is moment-rotation relationship instead of momentcurvature. Also, moment rotation data have been reduced to five-point input that brings some inevitable simplifications. Plastic hinge length is used to obtain ultimate rotation values from the ultimate curvatures. Several plastic hinge lengths have been proposed in 
the literature $[29,30]$. In this study plastic hinge length definition given in Eqn. 3.2 which is proposed by Priestley et al. is used.

$$
L_{p}=0.08 L+0.022 f_{y h} d_{b 1} \geq 0.044 f_{y h} d_{b 1}
$$

In Eqn. 2, $\mathrm{L}_{\mathrm{p}}$ is the plastic hinge length, $\mathrm{L}$ is the distance from the critical section of the plastic hinge to the point of contraflexure, $d_{b l}$ is the diameter of longitudinal reinforcement.

Following the calculation of the ultimate rotation capacity of an element, acceptance criteria are defined as labeled IO, LS, and CP on Fig. 2. IO, LS, and CP stand for Immediate Occupancy, Life Safety, and Collapse Prevention, respectively. This study defines these three points corresponding to $10 \%, 60 \%$, and $90 \%$ use of plastic hinge deformation capacity. In existing reinforced concrete buildings, especially with low concrete strength and/or insufficient amount of transverse steel, shear failures of members should be taken into consideration. For this purpose, shear hinges are introduced for beams and columns. Because of brittle failure of concrete in shear, no ductility is considered for this type of hinges. Shear hinge properties are defined such that when the shear force in the member reaches its strength, member fails immediately. The shear strength of each member $\left(V_{r}\right)$ is calculated according to TS 500 [23] that is similar to UBC [31]:

$$
V_{r}=0182 b d \sqrt{f_{c}}\left(1+0.07 \frac{N}{A_{c}}\right)+\frac{A_{s h} f_{y h} d}{s}
$$

In Eq. (3), $b$ is section width, $d$ is effective section depth, $f_{c}$ is concrete compressive strength, $\mathrm{N}$ is compression force on section, $\mathrm{A}_{\mathrm{c}}$ is area of section, $\mathrm{A}_{\mathrm{sh}}, \mathrm{f}_{\mathrm{yh}}$ and $\mathrm{s}$ are area, yield strength and spacing of transverse reinforcement, respectively.

Effect of infill walls are modeled through diagonal struts as suggested in TBEC-2018 and FEMA-356. Nonlinear behavior of infill walls is reflected by assigned axial load plastic hinges on diagonal struts whose characteristics are determined as given in FEMA-356. Material properties are taken from TBEC-2018 to reflect characteristics of infill walls in Turkey; $1000 \mathrm{MPa}, 1 \mathrm{MPa}$ and $0.15 \mathrm{MPa}$ were assumed as modulus of elasticity, compressive strength and shear strength values, respectively.

It may be noted that the conducted analyses are unidirectional, the out-of plane behaviour of infill walls and bidirectional effects of dynamic loading are not considered in scope of the study. The slip possibility of the longitudinal steel bars is not taken into account, as well.

\section{Nonlinear Static Analysis and Performance Evaluation}

In order to obtain capacity curves and displacement capacity values of the building models for different performance levels, nonlinear static analyses are carried out using SAP2000. The lateral forces applied at center of mass were proportional to the product of mass and the first mode shape amplitude at each story level under consideration. P-Delta effects were taken into account. Performance evaluation of the investigated buildings is conducted using Turkish Building Earthquake Code (2018). Three damage states as given in Figure 3, Immediate Occupancy (IO), Life Safety (LS), and Collapse Prevention (CP) are considered as specified in this code and several other international guidelines such as FEMA-356, ATC-40. 


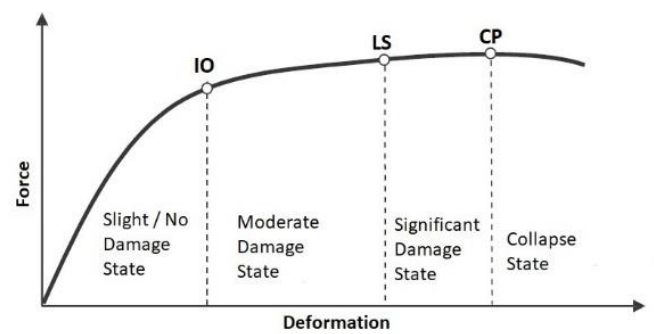

Fig. 3 Damage states

\section{Nonlinear Response History Analyses}

In order to investigate the soft story behavior on the drift demands nonlinear response history analyses are carried out. The capacity curve of each building obtained from pushover analysis was approximated with a bilinear curve using guidelines given in ATC40 and FEMA-440 and reduced to equivalent SDOF systems [21, 25]. Then these SDOF systems are subjected to nonlinear response history analysis by using ground motion record sets. USGS site classification based on the average shear wave velocity to a depth of $30 \mathrm{~m}$ is used for soil site classification of the selected records. Four site classifications include 83 different records, approximately 20 records for each soil type. Soil type A is the stiffest soil type with highest shear wave velocity and D is the weakest soil with the lowest shear wave velocity. All earthquake records are taken from PEER website [32]. Average values for some properties of selected ground motion records are given in Table 2 .

Table 2 Average values for some properties of used ground motion records

\begin{tabular}{cccccc}
\hline Soil Type & Number of records & Magnitude & PGA (g) & PGV (m/s) & PGD (m) \\
\hline A & 20 & 7.00 & 0.40 & 0.30 & 0.11 \\
B & 23 & 6.71 & 0.39 & 0.36 & 0.11 \\
C & 20 & 7.02 & 0.40 & 0.43 & 0.19 \\
D & 20 & 7.05 & 0.26 & 0.36 & 0.20 \\
\hline
\end{tabular}

\section{Analyses Results}

The capacity curves are obtained from the pushover analysis. Figure 4 shows capacity curves of the 7-story buildings. Also figure 5 shows the effect of amount of transverse reinforcement for 4-story buildings.

The global drift (GD) capacities (roof displacement/building height) of the building models for Immediate Occupancy (IO), Life Safety (LS), and Collapse Prevention (CP) performance levels are listed in 3 and 4 for 4 - and 7-story buildings, respectively. The "s100" and "s200" terms in the model name express the spacing of the transverse reinforcement in $\mathrm{mm}$. The ratio of the given values in tables to the corresponding value for the reference building is presented in the "/Ref" column. The ratio of lateral strength of the building to the weight of the building at the given capacity is provided in the column denoted by " $\mathrm{C}$ ". For the evaluation of the soft story behavior on the drift demands, results of nonlinear response analyses are used. The ratio of average drift demands of the soft story models to the corresponding reference model demands at the ground story for each soil type is given in Table 5. Since post-yield stiffness of the buildings was considerably small, the effect of transverse reinforcement amount only changes the ultimate displacement point and don't 
affect the SDOF idealization. Thus, drift demand evaluation is carried out regardless of transverse reinforcement spacing.

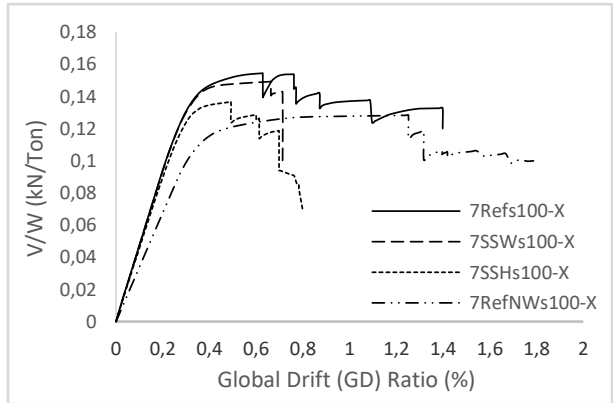

Fig. 4 Capacity curves of 7-story buildings

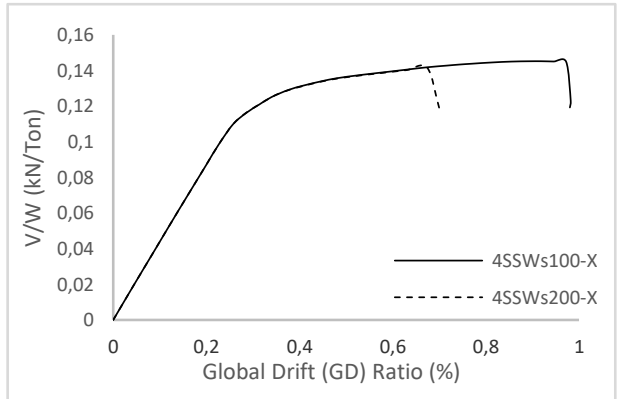

Fig. 5 Capacity curves of 4-story buildings for different transverse reinforcement amount

Table 3 Global drift capacities (\%) at given performance levels for the building models for 4-story buildings

\begin{tabular}{|c|c|c|c|c|c|c|c|c|c|c|c|c|}
\hline \multirow[b]{2}{*}{ Model } & \multicolumn{4}{|c|}{ IO } & \multicolumn{4}{|c|}{ LS } & \multicolumn{4}{|c|}{ CP } \\
\hline & GD & $/ \operatorname{Ref}$ & $\mathrm{C}$ & $/ \operatorname{Ref}$ & GD & $/ \operatorname{Ref}$ & $\mathrm{C}$ & $/ \operatorname{Ref}$ & GD & $/ \operatorname{Ref}$ & $\mathrm{C}$ & $/ \mathrm{Re}$ \\
\hline Refs & 0.53 & 1.00 & 18 & 1.00 & 1.08 & 1.00 & 0.17 & 1.00 & 1.45 & 1.00 & 17 & 1. \\
\hline & 0.23 & 1.00 & 0.20 & 1.00 & 0.59 & 1.00 & 0.22 & 1.00 & 0.84 & 1.00 & 0.17 & 1.00 \\
\hline $\operatorname{Re}$ & 0.50 & 1.00 & 0.18 & 1.00 & 0.68 & 1.00 & 0.18 & 1.00 & 1.15 & 1.00 & 0.17 & 1.00 \\
\hline Ref & 0 & 1.00 & 0.18 & 1.00 & 0.40 & 1.00 & 25 & 1.00 & 0.63 & 1.00 & 0.22 & 1.00 \\
\hline RefN & 1 & 0.96 & 14 & 0.76 & 0.90 & 0.83 & 14 & 0.84 & 1.36 & 0.94 & 0.14 & 0.85 \\
\hline s100-Y & 0.30 & 1.32 & 0.12 & 0.58 & 0.78 & 1.33 & 0.15 & 0.70 & 1.21 & 1.44 & 0.15 & 0.89 \\
\hline RefNWs200-X & 0.44 & 0.89 & 0.13 & 0.74 & 0.68 & 1.00 & 0.14 & 0.75 & 0.99 & 0.86 & 0.14 & 0.83 \\
\hline RefN & 0.25 & 1.28 & 0.10 & 0.56 & 0.57 & 1.42 & 0.15 & 0.59 & 0.86 & 1.36 & 0.15 & 0.69 \\
\hline SSH & 0.33 & 0.62 & 0.16 & 0.87 & 0.81 & 0.74 & 0.16 & 0.97 & 1.22 & 0.84 & 0.12 & 0.73 \\
\hline SS & 0 & 0.96 & 0.17 & 0.85 & 0.49 & 0.84 & 0.16 & 0.73 & 0.69 & 0.82 & 0.15 & 0.85 \\
\hline & 0 & 0.61 & 5 & 0.85 & 0.46 & 0.68 & .17 & 0.91 & 0.82 & 0.72 & 0.16 & 0.97 \\
\hline $\mathrm{SSH}$ & 0.19 & 0.98 & 0.16 & 0.86 & 0.37 & 0.94 & 0.22 & 0.86 & 0.47 & 0.74 & 0.22 & 1.00 \\
\hline SSW & 0.28 & 0.52 & 0.16 & 0.87 & 0.68 & 0.63 & 0.17 & 0.99 & 1.15 & 0.79 & 0.15 & 0.90 \\
\hline SSWs100-Y & 0.16 & 0.71 & 0.13 & 0.66 & 0.38 & 0.64 & 0.20 & 0.94 & 0.69 & 0.82 & 0.20 & 1.17 \\
\hline SSWs200-X & 0.24 & 0.48 & 0.15 & 0.81 & 0.37 & 0.54 & 0.17 & 0.92 & 0.83 & 0.72 & 0.15 & 0.88 \\
\hline SSWs & 0.13 & 0.67 & 0.11 & 0.61 & 0.24 & 0.61 & 0.18 & 0.72 & 0.44 & 0.69 & 0.21 & 0.93 \\
\hline SSHWs100-X & 0.26 & 0.48 & 0.12 & 0.64 & 0.55 & 0.50 & 0.14 & 0.82 & 0.88 & 0.60 & 0.14 & 0.86 \\
\hline SSHWs100-Y & 0.17 & 0.74 & 0.10 & 0.47 & 0.42 & 0.72 & 0.15 & 0.69 & 0.65 & 0.78 & 0.15 & 0.84 \\
\hline SSHWs200-X & 0.23 & 0.46 & 0.11 & 0.61 & 0.37 & 0.54 & 0.13 & 0.71 & 0.61 & 0.53 & 0.14 & 0.84 \\
\hline SSHWs200-Y & 0.15 & 0.73 & 0.08 & 0.46 & 0.28 & 0.70 & 0.14 & 0.54 & 0.45 & 0.71 & 0.15 & 0.68 \\
\hline
\end{tabular}


Table 4 Global drift capacities (\%) at given performance levels for the building models for 7-story buildings

\begin{tabular}{ccccccccccccc}
\hline & \multicolumn{1}{c}{ IO } & \multicolumn{1}{c}{ LS } & \multicolumn{1}{c}{ CP } \\
\cline { 2 - 7 } & GD & /Ref & C & /Ref & GD & /Ref & C & /Ref & GD & /Ref & C & /Ref \\
\hline Refs100-X & 0.43 & 1.00 & 0.15 & 1.00 & 0.65 & 1.00 & 0.15 & 1.00 & 1.40 & 1.00 & 0.13 & 1.00 \\
Refs100-Y & 0.36 & 1.00 & 0.18 & 1.00 & 0.48 & 1.00 & 0.19 & 1.00 & 0.68 & 1.00 & 0.19 & 1.00 \\
Refs200-X & 0.38 & 1.00 & 0.15 & 1.00 & 0.59 & 1.00 & 0.15 & 1.00 & 0.83 & 1.00 & 0.14 & 1.00 \\
Refs200-Y & 0.31 & 1.00 & 0.17 & 1.00 & 0.46 & 1.00 & 0.18 & 1.00 & 0.58 & 1.00 & 0.19 & 1.00 \\
RefNWs100-X & 0.52 & 1.19 & 0.12 & 0.82 & 0.95 & 1.45 & 0.13 & 0.87 & 1.25 & 0.89 & 0.13 & 0.97 \\
RefNWs100-Y & 0.51 & 1.40 & 0.13 & 0.73 & 0.89 & 1.86 & 0.14 & 0.74 & 1.28 & 1.87 & 0.14 & 0.73 \\
RefNWs200-X & 0.48 & 1.25 & 0.12 & 0.83 & 0.81 & 1.36 & 0.13 & 0.83 & 1.02 & 1.24 & 0.13 & 0.91 \\
RefNWs200-Y & 0.43 & 1.40 & 0.13 & 0.75 & 0.62 & 1.35 & 0.13 & 0.72 & 0.74 & 1.26 & 0.13 & 0.71 \\
SSHs100-X & 0.30 & 0.69 & 0.12 & 0.83 & 0.48 & 0.73 & 0.14 & 0.93 & 0.61 & 0.44 & 0.13 & 0.95 \\
SSHs100-Y & 0.27 & 0.74 & 0.15 & 0.83 & 0.41 & 0.87 & 0.17 & 0.88 & 0.60 & 0.88 & 0.17 & 0.88 \\
SSHs200-X & 0.27 & 0.70 & 0.11 & 0.79 & 0.37 & 0.63 & 0.13 & 0.87 & 0.49 & 0.59 & 0.14 & 0.97 \\
SSHs200-Y & 0.24 & 0.79 & 0.14 & 0.81 & 0.36 & 0.78 & 0.16 & 0.85 & 0.46 & 0.79 & 0.15 & 0.82 \\
SSWs100-X & 0.33 & 0.77 & 0.14 & 0.92 & 0.54 & 0.83 & 0.15 & 1.01 & 0.66 & 0.47 & 0.15 & 1.12 \\
SSWs100-Y & 0.25 & 0.68 & 0.14 & 0.81 & 0.38 & 0.80 & 0.17 & 0.91 & 0.54 & 0.80 & 0.18 & 0.92 \\
SSWs200-X & 0.30 & 0.78 & 0.13 & 0.89 & 0.43 & 0.72 & 0.15 & 0.95 & 0.57 & 0.69 & 0.15 & 1.05 \\
SSWs200-Y & 0.22 & 0.71 & 0.13 & 0.77 & 0.31 & 0.69 & 0.16 & 0.85 & 0.39 & 0.66 & 0.16 & 0.87 \\
SSHWs100-X & 0.25 & 0.58 & 0.11 & 0.71 & 0.40 & 0.61 & 0.12 & 0.85 & 0.60 & 0.43 & 0.13 & 0.96 \\
SSHWs100-Y & 0.19 & 0.52 & 0.10 & 0.57 & 0.32 & 0.67 & 0.14 & 0.72 & 0.47 & 0.69 & 0.14 & 0.76 \\
SSHWs200-X & 0.23 & 0.60 & 0.10 & 0.69 & 0.32 & 0.54 & 0.12 & 0.78 & 0.44 & 0.54 & 0.12 & 0.87 \\
SSHWs200-Y & 0.18 & 0.58 & 0.10 & 0.57 & 0.25 & 0.54 & 0.12 & 0.66 & 0.36 & 0.62 & 0.12 & 0.66 \\
\hline & & & & & & & & & & & &
\end{tabular}

Table 5 Ratio of average story drift demands at ground story for the building models subjected to ground motion record sets

\begin{tabular}{cccccccccccc}
\hline & \multicolumn{4}{c}{ 4-story } & \multicolumn{1}{c}{ 7-story } \\
\cline { 2 - 12 } & \multicolumn{4}{c}{ Drift Demand Ratio } & \multicolumn{5}{c}{ Drift Demand Ratio } \\
\cline { 2 - 12 } & B & C & D & Ave. & A & B & C & D & Ave. \\
\hline Ref-X & 1.00 & 1.00 & 1.00 & 1.00 & 1.00 & 1.00 & 1.00 & 1.00 & 1.00 & 1.00 \\
Ref-Y & 1.00 & 1.00 & 1.00 & 1.00 & 1.00 & 1.00 & 1.00 & 1.00 & 1.00 & 1.00 \\
SSH-X & 1.34 & 1.17 & 1.26 & 1.35 & 1.28 & 1.34 & 1.33 & 1.37 & 1.41 & 1.33 \\
SSH-Y & 1.14 & 1.26 & 1.23 & 1.34 & 1.28 & 1.41 & 1.43 & 1.32 & 1.45 & 1.41 \\
SSW-X & 1.60 & 1.59 & 1.55 & 1.63 & 1.58 & 1.24 & 1.21 & 1.22 & 1.25 & 1.23 \\
SSW-Y & 1.69 & 1.89 & 1.83 & 2.00 & 1.90 & 1.55 & 1.55 & 1.43 & 1.55 & 1.51 \\
SSHW-X & 1.95 & 1.78 & 1.91 & 2.02 & 1.93 & 1.78 & 1.75 & 1.86 & 1.78 & 1.75 \\
SSHW-Y & 2.23 & 2.21 & 2.21 & 2.66 & 2.38 & 2.05 & 2.07 & 2.04 & 2.18 & 2.06 \\
\hline Average & 1.49 & 1.49 & 1.50 & 1.63 & & 1.42 & 1.42 & 1.41 & 1.45 & \\
\hline & & & & & & & & & & \\
\hline
\end{tabular}




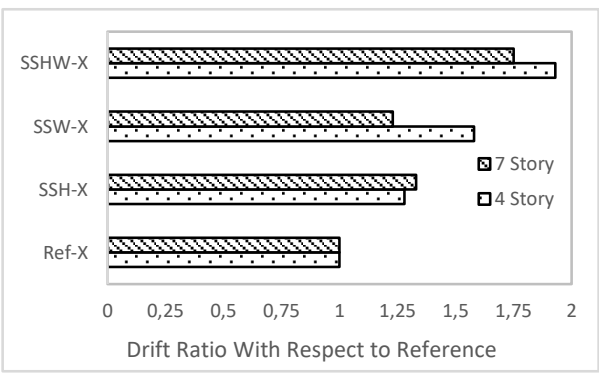

Fig. 6 Average drift demand ratios for ground story at $\mathrm{X}$ axis

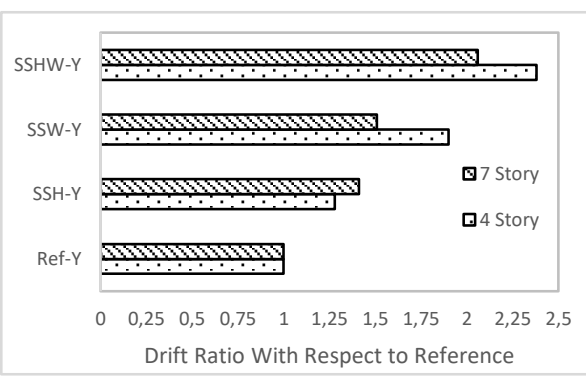

Fig. 7 Average drift demand ratios for ground story at $\mathrm{Y}$ axis

\section{Results and Discussion}

In this study, soft story behavior due to increased story height, lack of load bearing infill wall at ground story and existence of both cases are investigated using nonlinear static and dynamic response history analyses for mid-rise reinforced concrete buildings. Based on 40 nonlinear static analyses and 1328 nonlinear response history analyses the following observations are made:

- Although, transverse steel amount has limited effect on lateral strength, it significantly affects the displacement capacities (Table 3 and 4). Even though s100 and s200 models have the same yield strength, the displacement capacities of the s200 models are considerably lower (Fig. 5).

- Consideration of infill walls in the building model as diagonal struts increases the yield strength of the 4 - and 7-story models by $45 \%$ and \%32, respectively (Fig. 5 and Table 1). Modeling of infill walls seems to be more effective on the lateral strength of the buildings with less number of stories, because the properties of the walls are not affected by the number of stories but the floor plan. Structural elements with larger dimension and strength in the buildings with more number of stories decrease the effect of walls.

- In general, the lateral strength of the building increases, and displacement capacity decreases when infill walls are regarded as load carrying elements (Fig. 5 , Table 3 and 4).

- When Table 3 is examined, it is observed that for some instances, the displacement capacities of the Soft Story due to Height and Wall (SSHW) model is higher than that of Soft Story due to Wall (SSW) ones on the contrary of the expectations. This is due to the increase in plastic hinge length, hence rotation capacity, because of increased column length at ground story (Eqn. 2). In view of the values used in the study, elongation of column length from $2.8 \mathrm{~m}$ to $4 \mathrm{~m}$ increases plastic rotation capacity of the columns by $35 \%$ on the average. Even though this increase, no such instance is encountered in the 7-story models.

- In order to determine which soft story case has the most negative effect on the displacement capacity, the ratio of the irregular model capacities to the regular ones ("/Ref" column) is considered. For Life Safety performance level: average values are 0.80 for SSH, 0.60 for SSW, 0.62 for SSHW models. Therefore, the most detrimental case for the 4-story buildings is the SSW with slight difference with SSHW due to the above explained reasons. These figures for the 7-story buildings 
are, SSH: 0.75, SSW: 0.76, SSHW: 0.59. Therefore, SSHW case is the most unfavorable one (Table 3 and 4).

- $\quad$ SSHW case is the most unfavorable one for both 4- and 7-story buildings for Collapse Prevention level (Table 3 and 4). The average values are; SSH: 0.78, SSW: 0.76, SSHW: 0.66 for 4-story, and SSH: 0.67, SSW: 0.66, SSHW: 0.57 for 7-story, for the Collapse Prevention level.

- Soft story which is especially due to height and wall increased the story drift ratios considerably as shown in Figure 6 and 7. The demands due to soft story may increase up to $100 \%$.

- Although there is no obvious effect of ground motion records on different soil types in story drift demands for 7-story buildings, the demands of the 4-story buildings are observed to be affected for soil type D.

After the results of this study and the studies of Arteta et al [10] , Bozyigit and Yesilce [14] are accounted, it is seen that the infill walls significantly changed the behavior of the structure. If infill walls are regarded as load carrying elements, the lateral strength of the building increases, and displacement capacity decreases as reported in Harsoor and Shreenath's study [12] and Santhi's study [13]. When the obtained displacement capacity and drift demand results are evaluated, in scope of the values considered in the study, it is observed that soft story due to increased height (SSH) and due to lack of infill walls (SSW) have close values to each other. As a result, it should be kept in mind that soft story may arise not only because of increased story height, but because of abrupt changes in amount of infill walls which are not thought to be a part of structural system. As observed in this study, soft story due to increased height and lack of infill wall at ground story (both at the same time) is the most detrimental case in view of drift capacities and demands.

\section{Acknowledgement}

The authors acknowledge support provided by Scientific and Technical Research Council of Turkey (TUBITAK) under Project No: 105M024.

\section{References}

[1] Adalier K, Aydingun 0. Structural engineering aspects of the June 27, 1998 AdanaCeyhan (Turkey) earthquake, Engineering Structures, 2001; 23:343-55. https://doi.org/10.1016/S0141-0296(00)00046-8

[2] Dogangun A. Performance of reinforced concrete buildings during the May 12003 Bingöl earthquake in Turkey, Engineering Structures, 2004; 26:6; 841 - 856. https://doi.org/10.1016/j.engstruct.2004.02.005

[3] Kaplan H. Yilmaz S. Binici H. Yazar E. Cetinkaya N. May 1, 2003 Turkey-Bingöl Earthquake: Damage in Reinforced Concrete Structures, Engineering Failure Analysis, 2004; 11: 279 - 291. https://doi.org/10.1016/j.engfailanal.2003.08.005

[4] Ozcebe G. Seismic assessment and rehabilitation of existing buildings. Tubitak Research Report; Report No: ICTAG YMAU I574: Ankara, Turkey, 2004.

[5] Sezen H. Whittaker AS. Elwood KJ. Mosalam KM. Performance of reinforced concrete buildings during the August 17, 1999 Kocaeli, Turkey earthquake, and seismic design and construction practice in Turkey, Engineering Structures, 2003; 25:1, 103 - 114. https://doi.org/10.1016/S0141-0296(02)00121-9

[6] Sucuoglu H. Yilmaz T. Duzce, Turkey: a city hit by two major earthquakes in 1999 within three months, Seismological Research Letters, 2001; 72:6 679 - 689. https://doi.org/10.1785/gssrl.72.6.679 
[7] Dolsek M. Fajfar P. Soft storey effects in uniformly infilled reinforced concrete frames, Journal of Earthquake Engineering, 2000; $5: 1 \quad 1 \quad-\quad 12$. https://doi.org/10.1080/13632460109350383

[8] Negro P. Colombo A. Irregularities induced by nonstructural masonry panels in framed buildings, Engineering Structures, 1997; $19: 7 \quad 576 \quad-\quad 585$. https://doi.org/10.1016/S0141-0296(96)00115-0

[9] Avşar Ö. Aksoy HB. Dolgu Duvarların Betonarme Çerçeve Davranışına Etkisinin Basitleştirilmiş Bir Yöntemle Dikkate Alınması, Pamukkale Üniv. Müh. Bilim Derg., 2015; 21:3 115 - 122. [in Turkish]

[10] Arteta CA. Carrillo J. Archbold J. Gaspar D. Pajaro C. Araujo G. Torregroza A. Bonett R. Blandon C. Fernandez-Sola LR. Correal JF. Mosalam KM. Response of Mid-Rise Reinforced Concrete Frame Buildings to the 2017 Puebla Earthquake, Earthquake Spectra, 2019; 35:4 1763 - 1793. https://doi.org/10.1193/061218EQS144M

[11] Ozmen HB. Inel M. Strength reduction factors for existing mid-rise RC buildings for different performance levels. Res. Eng. Struct. Mat., 2018; 4(4): 241-255. https://doi.org/10.17515/resm2018.60ea3107

[12] Shreenath Harsoor R. Effect of infill wall on vertical irregular tall structure, International Journal of Innovative Technology and Exploring Engineering, 2019; 9(1): 1488-1495. https://doi.org/10.35940/ijitee.A4303.119119

[13] Santhi MH. Evaluation of earthquake load resistance of masonry infilled RC frames using linear and non-linear dynamic analysis, 14th International Conference on Concrete Engineering and Technology, 2018; Kuala Lumpur; Malaysia. https://doi.org/10.1088/1757-899X/431/12/122010

[14] Bozyigit B. Yesilce Y. Effects Of Infill Walls On Free Vibration Characteristics Of MultiStorey Frames Using Dynamic Stiffness Method, Sigma J Eng \& Nat Sci, 2019; 37:3 885 - 902. https://doi.org/10.1002/eqe.2555

[15] Jeon JS., Park JH. DesRoches R. Seismic fragility of lightly reinforced concrete frames with masonry infills, Earthquake Engng Struct. Dyn. 2015; 44:1783 - 1803

[16] Quayyum S. Alam MS. Rteil A. Seismic behavior of soft storey mid-rise steel frames with randomly distributed masonry infill, Steel and Composite Structures, 2013; 14:6 523 - 545. https://doi.org/10.12989/scs.2013.14.6.523

[17] Serenaj A. Garevski M. The required ductility reduction of soft storey buildings through application of base isolation. Res. Eng. Struct. Mat., 2018; 4(1): 49-60.

[18] Turkish Earthquake Code (TEC), Specifications for buildings to be built in seismic areas, Ministry of Public Works and Settlement, Ankara, Turkey, 1975. [in Turkish]

[19] Turkish Earthquake Code (TEC), Specifications for buildings to be built in seismic areas, Ministry of Public Works and Settlement, Ankara, Turkey, 2018. [in Turkish]

[20] SAP2000 V-8, CSI. Integrated finite element analysis and design of structures basic analysis reference manual; Berkeley (CA, USA); Computers and Structures Inc.

[21] Federal Emergency Management Agency (FEMA). Prestandard and Commentary for Seismic Rehabilitation of Buildings. Rep. FEMA-356, Washington D.C., USA, 2000.

[22] Watanabe F. Behaviour of Reinforced Concrete Buildings during Hyougoken-Nanbu Earthquake, Cement and Concrete Composites, 1997; 19: 203 - 211. https://doi.org/10.1016/S0958-9465(97)00013-9

[23] TS500, Design and Construction Specifications for Reinforced Concrete Structures, Turkish Standards Institute, Ankara, Turkey, 2000. [in Turkish]

[24] Inel, M., Ozmen, H. B., \& Bilgin, H. (2008). Re-evaluation of building damage during recent earthquakes in Turkey. Engineering Structures, 30(2), 412-427. https://doi.org/10.1016/i.engstruct.2007.04.012

[25] Applied Technology Council (ATC). Seismic Evaluation and Retrofit of Concrete Buildings, Rep. No. ATC-40, Redwood City, California, USA, 1996. 
[26] Scott BD. Park R. Priestley MJN. Stress-strain behavior of concrete confined by overlapping hoops at low and high strain rates, ACI Structural Journal, 1982; 76:1 13 27.

[27] Mander JB. (1984). Seismic Design of Bridge Piers, Ph.D. Dissertation, University of Canterbury, New Zealand.

[28] Turkish Earthquake Code (TEC), Specifications for buildings to be built in seismic areas, Ministry of Public Works and Settlement, Ankara, Turkey, 2007. [in Turkish]

[29] Priestley MJN. Seible F. Calvi GMS. Seismic Design and Retrofit of Bridges, John Wiley \& Sons, New York, NY, USA, 1996. https://doi.org/10.1002/9780470172858

[30] Park R. Paulay T. Reinforced Concrete Structures, John Wiley \& Sons, New York, NY, USA, 1975. https://doi.org/10.1002/9780470172834

[31] Uniform Building Code (UBC), Int. Conf. of Building Officials, Whittier, California, USA, 1997.

[32] PEER, Pacific Earthquake Engineering Research Center, http://peer.berkeley.edu/smcat/index.html. 